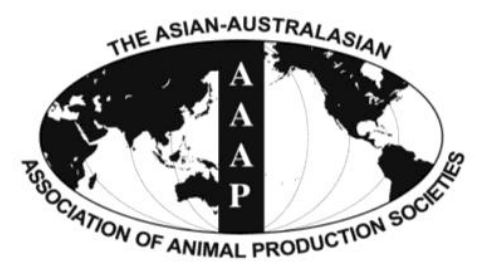

Asian-Aust. J. Anim. Sci.

Vol. 25, No. 3 : 353 - 360

March 2012

www.ajas.info

http://dx.doi.org/10.5713/ajas.2011.11426

\title{
Evaluation of Milk Trace Elements, Lactate Dehydrogenase, Alkaline Phosphatase and Aspartate Aminotransferase Activity of Subclinical Mastitis as and Indicator of Subclinical Mastitis in Riverine Buffalo (Bubalus bubalis)
}

\author{
Anirban Guha*, Sandeep Gera and Anshu Sharma \\ Department of Veterinary Physiology and Biochemistry, College of Veterinary Sciences, \\ Lala Lajpat Rai University of Veterinary and Animal Sciences, Hisar - 125004, Haryana, India
}

\begin{abstract}
Mastitis is a highly morbid disease that requires detection at the subclinical stage. Tropical countries like India mainly depend on milch buffaloes for milk. The present study was conducted to investigate whether the trace minerals viz. copper $(\mathrm{Cu})$, iron $(\mathrm{Fe})$, zinc $(\mathrm{Zn})$, cobalt $(\mathrm{Co})$ and manganese $(\mathrm{Mn})$ and enzyme activity of lactate dehydrogenase (LDH), alkaline phosphatase (ALP) and aspartate aminotransferase (AST) in riverine buffalo milk can be used as an indicator of subclinical mastitis (SCM) with the aim of developing suitable diagnostic kit for SCM. Trace elements and enzyme activity in milk were estimated with Atomic absorption Spectrophotometer, GBC 932 plus and biochemical methods, respectively. Somatic cell count (SCC) was done microscopically. The cultural examination revealed Gram positive bacteria as the most prevalent etiological agent. A statistically significant $(\mathrm{p}<0.01)$ increase in SCC, Fe, Zn, Co and LDH occurred in SCM milk containing gram positive bacterial agents only. ALP was found to be elevated in milk infected by both gram positive and negative bacteria. The percent sensitivity, specificity and accuracy, predictive values and likelihood ratios were calculated taking bacterial culture examination and SCC $\geq 2 \times 10^{5}$ cells $/ \mathrm{ml}$ of milk as the benchmark. Only ALP and $\mathrm{Zn}$, the former being superior, were found to be suitable for diagnosis of SCM irrespective of etiological agents. LDH, Co and Fe can be introduced in the screening programs where Gram positive bacteria are omnipresent. It is recommended that both ALP and Zn be measured together in milk to diagnose buffalo SCM, irrespective of etiology. (Key Words : Riverine Buffalo, Somatic Cell Count, Subclinical Mastitis, Indicator, Trace Minerals, Enzyme Activity)
\end{abstract}

\section{INTRODUCTION}

Mastitis causes physical, chemical and bacteriological alternation in the milk and blood along with morphopatholological changes in the mammary gland. It causes a great economic loss in the dairy industry, world-wide. Subclinical mastitis (SCM) is a herd problem and frequently overlooked, causing additional economic loss (Gera et al., 2006). SCM detection is precluded due to pooling of milk for sale from the village or the farm and as a result of which the source of the SCM milk cannot be determined after collection (Gera and Guha, 2011a). For years many workers tried to develop several indirect tests, but, unfortunately none proved satisfactory to diagnose SCM (Guha et al. 2010).

\footnotetext{
* Corresponding Author : Anirban Guha. Tel : +91-9836341948, E-mail : archies76@gmail.com

Submitted Nov. 15, 2011; Accepted Dec. 17, 2011; Revised Dec. 23, 2011
}

Somatic cell count (SCC) associated with an inflammatory state is generally employed for diagnosing SCM but has a few limitations, hence a positive diagnosis of mastitis needs to fulfill two criteria viz. a positive bacteriological test and an inflammatory change (Katsoulos, et al., 2010). However, the logistic and financial considerations involved with sampling all fresh milk samples have precluded these techniques from being widely adopted. Although these parameters indicate inflammation (Guha et al., 2010; Gera and Guha 2011a) alternative parameters are required to identify trends in the development of the udder health in a dairy herd.

Milch buffaloes were earlier thought to be less susceptible to mastitis compared to cows, but similar frequencies for both the species were reported in the recent past from different quarters (Moroni et al., 2006). The development of immuno-modulatory strategies and the search for putative indicators for control of bubaline 
subclinical mastitis is currently an active area of research as developing tropical nations like India mostly utilize buffalo milk rather than cow milk. The neuroendocrine system, immune system and mineral metabolism interact to coordinate physiological responses to infection and inflammation (Ma et al., 2006; Gera et al., 2011). Also, the inflammatory products tend to damage udder parenchyma which results in release of intra-cellular enzyme activity (Babaei et al., 2007). The present study was undertaken to evaluate the role of SCM on the changes occurring in concentration of trace minerals viz. copper $(\mathrm{Cu})$, iron $(\mathrm{Fe})$, zinc ( $\mathrm{Zn})$, manganese $(\mathrm{Mn})$ and cobalt $(\mathrm{Co})$ and the activity of the enzymes such as lactate dehydrogenase (LDH), alkaline phosphatase (ALP) and aspartate aminotransferase (AST) activity in Murrah buffalo milk and assessing them as a possible indicator of SCM in riverine buffalo (Bubalus bubalis). Timely detection of SCM in riverine buffaloes will prevent tons of milk being wasted and will have a positive effect on economy of the developing tropical countries.

\section{MATERIALS AND METHODS}

\section{Sampling}

Milk samples were collected aseptically from 514 (2,048 quarters) Murrah buffaloes of different age groups with apparently healthy quarters. The animals had no history of mastitis. Sampling was done from different districts of Haryana, India.

\section{Microbial culture examination}

With a $4 \mathrm{~mm}$ diameter platinum loop $0.01 \mathrm{ml}$ of the sample was streaked on $5 \%$ ovine blood agar plates. The plates were incubated aerobically at $37^{\circ} \mathrm{C}$ for $24 \mathrm{~h}$. The resulting growth from the respective plates of media was purified and identified on the basis of morphology, colony characteristics and Gram's reaction (Hokmabad et al., 2011).

\section{Estimation of somatic cells}

The somatic cells were counted microscopically (Gera et al., 2011). Briefly: Following thorough mixing of milk samples and with a $4 \mathrm{~mm}$ diameter platinum loop, $0.01 \mathrm{ml}$ of milk was spread evenly over four $1.0 \mathrm{~cm}^{2}$ area template outlines. Slides were stained for $30 \mathrm{~s}$ in Newman-Lampert stain, the composition as follows:

\section{Methylene blue : $1.2 \mathrm{gm}$ \\ 95\% ethyl alcohol : $54 \mathrm{ml}$ \\ Tetrachloroethane : $40 \mathrm{ml}$ \\ Glacial acetic acid : $6 \mathrm{ml}$}

Somatic cells were stained with deep blue nuclei against light blue background. The working factor of the microscope was calculated to be 35,400 by using stage micrometer, calculating diameter of the microscopic field $(0.012 \mathrm{~cm})$ and field per square $\mathrm{cm}(8,850)$ for the given microscope. Total no. of cells was obtained by multiplying the total no. of cells counted in 25 fields with the working factor.

\section{Estimation of milk enzyme activity}

The enzyme activity of LDH, ALP and AST in milk samples were estimated by commercial kit manufactured by Bayers Co. Ltd. with Spectralab II autoanalyzer. The standardized protocol provided with the kit was followed for estimation.

\section{Estimation of milk trace minerals}

All the trace elements were estimated with Atomic Absorption Spectrophotometer GBC 932 plus. The milk samples were digested with di-acid mixture (nitric acid and per chloric acid at the ratio 4:1) (Gera et al., 2011). The residues were dissolved in distilled water and the final volume was made up to $50 \mathrm{ml}$ for copper, cobalt and manganese (dilution factor $=25$ ). For iron and zinc the dilution factor was 50. The dilutions were done as per the instruction manual provided with the Spectrophotometer GBC 932 plus.

\section{Calculation of percent sensitivity, specificity, accuracy, predictive values and likelihood ratios}

Percent sensitivity, specificity, accuracy, predictive values and likelihood ratios were found taking IDF criteria i.e. bacterial growth in culture media and $\mathrm{SCC} \geq 2 \times 10^{5}$ cells/ml of milk as benchmark (Katsoulos et al., 2010; Gera and Guha, 2011b). The cut-off values for each significantly altered parameter were obtained from Receiver Operator Characteristic (ROC) analysis curve with the aid of the MedCalc software. The percent sensitivity, specificity, accuracy, positive and negative predictive value and likelihood ratios (both positive and negative) was calculated by the formulae of Petrie and Watson (2008).

\section{Statistical analysis}

Analysis of variance (ANOVA) and Duncan Multiple Range Test were carried out to compare the milk components. Comparison of means of estimated concentration of different parameters in healthy and SCM milk, irrespective of the etiology, was done by t-test. SCC was converted to $\log _{10} \mathrm{SCC}$. Pearson's correlation coefficient among milk components showing substantial alternation in concentration between normal and SCM milk samples including $\log _{10} \mathrm{SCC}$ was also calculated. Scattered plot graphs were plotted to describe the correlation between $\mathrm{Zn}$ and ALP in healthy as well as in SCM milk. All statistical analysis was done with SPSS statistical software (Petrie and Watson, 2008). 
Table 1. Prevalence of bacterial agents in subclinical mastitis milk of riverine buffalo (Bubalus bubalis)

\begin{tabular}{lrrrrr}
\hline \multirow{2}{*}{ Genus } & \multicolumn{2}{c}{ Animal } & & \multicolumn{2}{c}{ Quarters } \\
\cline { 5 - 6 } & Number & Percentage & & Number & Percentage \\
\hline Staphylococcus spp. & 119 & 44 & & 223 & 45 \\
Streptococcus spp. & 95 & 35 & & 169 & 34 \\
Escherichia coli & 49 & 18 & 84 & 17 & 4 \\
Others (Corynebacterium spp. and Bacillus spp.)+mixed infection & 8 & 3 & & 20 & 100 \\
Total & 271 & 100 & 496 & \\
\hline
\end{tabular}

\section{RESULTS}

\section{Etio-prevalence of SCM}

Milk samples which showed growth in culture media and $\mathrm{SCC} \geq 2 \times 10^{5}$ cells $/ \mathrm{ml}$ of milk were considered SCM positive. In this study, on the basis of bacterial culture examination and SCC, it was observed that 271 riverine buffaloes comprising 496 quarter milk samples to be SCM positive. The SCC was observed to increase significantly $(\mathrm{p}<0.01)$ in SCM milk for all infections (Tables 2 and 3). The mean SCC in SCM milk was $2.58 \pm 0.056 \times 10^{5}$ cells $/ \mathrm{ml}$ of milk (Table 3). From Table 1 it is evident that the most prevalent etiological agent was Staphylococcus spp. affecting $45 \%$ quarters. Streptococcus spp. (34\%) followed by Escherichia coli (17\%) were the next most frequently isolated bacterial agents. A few instances of mixed infection and Corunaebacterium spp. and Bacillus spp. were also encountered during the investigation (Table 1). Together the frequencies of Gram positive infections were $>79 \%$.

\section{Effect of SCM on milk components}

In this study it was observed (Tables 2 and 3) that the concentration of $\mathrm{Cu}, \mathrm{Mn}$ and AST were comparable in infected and normal milk. The concentration of Fe, Zn, Co and LDH activity increased significantly $(\mathrm{p}<0.01)$ only in gram positive SCM milk (Table. 2) whereas their concentration were comparable in normal and $E$. coli infected SCM milk. Also mean comparison of Fe, Zn, Co and $\mathrm{LDH}$ between infected and normal milk showed significant $(\mathrm{p}<0.01)$ increase (Table 3$)$. The concentration of ALP also increased significantly $(p<0.01)$ in SCM samples irespective of the etiological agent (Tables 2 and 3 ).

\section{Percent sensitivity, specificity, accuracy, predictive values and likelihood ratios}

After calculating the percent sensitivity, specificity, accuracy, predictive values and likelihood ratios for all the significantly altered parameters, ALP followed by $\mathrm{Zn}$ was most in agreement with IDF criteria for SCM considered irrespective of the causative agents (Tables 4 and 5). The likelihood ratios for ALP and Zn were 16.54 and 12.52 respectively. In the case of $\mathrm{Fe}, \mathrm{Co}$ and $\mathrm{LDH}$ apart from percent specificity and negative predictive value all the other values were found to be too low to be useful in predicting SCM caused by Gram negative bacteria (Table 4), but there values were satisfactory and acceptable when we measured them in SCM milk infected by Gram positive bacteria only (Table 5). When both ALP and Zn was

Table 2. Effect of different bacterial agents on trace mineral and enzyme activity profile of normal and subclinical mastitis milk of riverine buffalo (Bubalus bubalis)

\begin{tabular}{|c|c|c|c|c|c|}
\hline \multirow[b]{2}{*}{ Parameters } & \multirow{2}{*}{$\begin{array}{c}\text { Mean } \pm \text { SE of } \\
\text { normal milk } \\
\quad(n=496)\end{array}$} & \multicolumn{4}{|c|}{$\begin{array}{l}\text { Mean } \pm \text { SE of subclinical mastitis milk } \\
\qquad(\mathrm{n}=496)\end{array}$} \\
\hline & & $\begin{array}{l}\text { Staphylococcus spp. } \\
\qquad(\mathrm{n}=223)\end{array}$ & $\begin{array}{l}\text { Sterptococcus spp. } \\
\quad(\mathrm{n}=169)\end{array}$ & $\begin{array}{l}\text { Escherichia coli } \\
\quad(\mathrm{n}=84)\end{array}$ & $\begin{array}{l}\text { Others+mixed } \\
\text { infection } \\
(\mathrm{n}=20)\end{array}$ \\
\hline $\begin{array}{l}\text { Somatic cell count } \\
\left(\times 10^{5} \text { cells } / \mathrm{ml}\right)\end{array}$ & $0.98 * \pm 0.037$ & $2.76 * * \pm 0.011$ & $2.59 * * \pm 0.024$ & $2.14 * * \pm 0.018$ & $2.27 * * \pm 0.062$ \\
\hline $\mathrm{Cu}(\mathrm{ppm})$ & $0.381 \pm 0.032$ & $0.402 \pm 0.018$ & $0.398 \pm 0.021$ & $0.376 \pm 0.032$ & $0.412 \pm 0.035$ \\
\hline $\mathrm{Fe}(\mathrm{ppm})$ & $3.05 * \pm 0.23$ & $5.41 * * \pm 0.11$ & $5.76 * * \pm 0.18$ & $3.33 * \pm 0.31$ & $5.48 * * \pm 0.43$ \\
\hline $\mathrm{Zn}(\mathrm{ppm})$ & $3.57 * \pm 0.27$ & $6.16^{* * \pm 0.19}$ & $6.73 * * \pm 0.21$ & $3.99 * \pm 0.45$ & $6.06 * * \pm 0.42$ \\
\hline Mn (ppm) & $0.56 \pm 0.11$ & $0.57 \pm 0.04$ & $0.59 \pm 0.08$ & $0.54 \pm .14$ & $0.57 \pm 0.14$ \\
\hline Co (ppm) & $0.029 * \pm 0.019$ & $0.107 * * \pm 0.023$ & $0.112 * * \pm 0.027$ & $0.032 * \pm 0.012$ & $0.114 * * \pm 0.033$ \\
\hline LDH (U/L) & $96.64 * \pm 31.64$ & $291.32 * * \pm 24.91$ & $301.92 * * \pm 26.45$ & $102.22 * \pm 33.21$ & $296.23 * * \pm 34.91$ \\
\hline $\operatorname{ALP}(\mathrm{U} / \mathrm{L})$ & $284.50 * \pm 31.57$ & $822.71 * * \pm 23.21$ & $798.87 * * \pm 28.22$ & $787.87 * * \pm 32.29$ & $812.98 * * \pm 34.09$ \\
\hline AST (U/L) & $23.32 \pm 1.35$ & $21.13 \pm 1.08$ & $24.65 \pm 1.12$ & $23.98 \pm 1.93$ & $22.67 \pm 1.11$ \\
\hline
\end{tabular}

Mean having different superscripts * and $* *$ horizontally differ significantly $(\mathrm{p}<0.01)$. 
Table 3. Mean \pm SE of SCC, trace minerals and enzyme activity in milk from normal and subclinical mastitis (irrespective of the causative agent) in riverine buffalo $(n=496)$

\begin{tabular}{lccc}
\hline Parameter & Normal milk & Subclinical mastitis milk & Cut-off points \\
\hline Somatic cell count $\left(\times 10^{5} \mathrm{cells} \mathrm{ml}^{-1}\right)$ & $0.98^{*} \pm 0.037$ & $2.58 * * \pm 0.056$ & - \\
$\mathrm{Cu}(\mathrm{ppm})$ & $0.381 \pm 0.032$ & $0.397 \pm 0.015$ & - \\
$\mathrm{Fe}(\mathrm{ppm})$ & $3.05 * \pm 0.23$ & $5.18^{* * \pm 0.09}$ & 5.20 \\
$\mathrm{Zn}(\mathrm{ppm})$ & $3.57 * \pm 0.27$ & $5.98 * * \pm 0.18$ & 6.01 \\
$\mathrm{Mn}(\mathrm{ppm})$ & $0.56 \pm 0.11$ & $0.57 \pm 0.02$ & - \\
Co $(\mathrm{ppm})$ & $0.029 * \pm 0.019$ & $0.096 * \pm 0.017$ & 0.099 \\
LDH (U/L) & $96.64 * \pm 31.64$ & $263.10 * * \pm 18.95$ & 266.11 \\
ALP $(\mathrm{U} / \mathrm{L})$ & $284.50 * \pm 31.57$ & $808.29 * * \pm 22.61$ & 811.12 \\
AST (U/L) & $23.32 \pm 1.35$ & $22.87 \pm 1.02$ & - \\
\hline
\end{tabular}

Mean having different superscripts * and $* *$ horizontally differ significantly $(\mathrm{p}<0.01)$.

Table 4. Evaluation of Fe, $\mathrm{Zn}, \mathrm{Co}, \mathrm{LDH}$ and ALP as an indicator for diagnosis of subclinical mastitis in riverine buffalo

\begin{tabular}{|c|c|c|c|c|c|c|c|c|c|c|c|c|c|}
\hline \multirow{2}{*}{$\begin{array}{l}\text { Name } \\
\text { of the } \\
\text { parameter }\end{array}$} & \multirow{2}{*}{$\begin{array}{c}\text { Total } \\
\text { samples } \\
\text { examined } \\
(\mathrm{N})\end{array}$} & \multirow{2}{*}{$\begin{array}{c}\text { Test } \\
\text { positive } \\
\text { samples } \\
(\mathrm{a}+\mathrm{b})\end{array}$} & \multicolumn{4}{|c|}{$\begin{array}{l}\text { Test reaction as compared to cultural } \\
\text { examination }\end{array}$} & \multirow{2}{*}{$\begin{array}{l}\text { Percent } \\
\text { sensitivity } \\
a /(a+d) \\
\times 100\end{array}$} & \multirow{2}{*}{$\begin{array}{l}\text { Percent } \\
\text { specificity } \\
\text { c/(b+c) } \\
\times 100\end{array}$} & \multirow{2}{*}{$\begin{array}{l}\text { Percent } \\
\text { accuracy } \\
(\mathrm{a}+\mathrm{c}) / \\
\mathrm{N} \times 100\end{array}$} & \multirow{2}{*}{$\begin{array}{c}\text { Positive } \\
\text { predictive } \\
\text { value }(\%) \\
\mathrm{a} /(\mathrm{a}+\mathrm{b}) \\
\times 100\end{array}$} & \multirow{2}{*}{$\begin{array}{c}\text { Negative } \\
\text { predictive } \\
\text { value }(\%) \\
\mathrm{c} /(\mathrm{c}+\mathrm{d}) \\
\times 100\end{array}$} & \multirow{2}{*}{$\begin{array}{c}\text { Likelihood } \\
\text { ratio } \\
\text { (positive) } \\
\text { sensitivity } \\
/(100- \\
\text { specificity) }\end{array}$} & \multirow{2}{*}{$\begin{array}{c}\text { Likelihood } \\
\text { ration } \\
\text { (negative) } \\
\quad(100- \\
\text { sensitivity) } \\
\text { /specificity }\end{array}$} \\
\hline & & & $\begin{array}{l}\text { True } \\
\text { positive } \\
\text { (a) }\end{array}$ & $\begin{array}{l}\text { False } \\
\text { positive } \\
\text { (b) }\end{array}$ & $\begin{array}{l}\text { True } \\
\text { negative } \\
\text { (c) }\end{array}$ & $\begin{array}{l}\text { False } \\
\text { negative } \\
\text { (d) }\end{array}$ & & & & & & & \\
\hline $\mathrm{Fe}$ & 2,048 & 253 & 172 & 81 & 1,471 & 324 & 34.67 & 94.78 & 80.22 & 67.98 & 94.78 & 6.64 & 0.69 \\
\hline $\mathrm{Zn}$ & 2,048 & 465 & 372 & 93 & 1,459 & 124 & 75.0 & 94.01 & 89.40 & 80.00 & 92.17 & 12.52 & 0.02 \\
\hline Co & 2,048 & 267 & 152 & 115 & 1,437 & 344 & 30.64 & 92.59 & 77.59 & 56.93 & 80.69 & 4.13 & 0.75 \\
\hline LDH & 2,048 & 287 & 170 & 117 & 1,435 & 326 & 34.27 & 92.46 & 78.37 & 59.23 & 81.49 & 4.55 & 0.71 \\
\hline ALP & 2,048 & 484 & 407 & 77 & 1,475 & 89 & 82.06 & 95.04 & 91.89 & 84.09 & 94.31 & 16.54 & 0.19 \\
\hline $\mathrm{Zn}+\mathrm{ALP}$ & 2,048 & 497 & 493 & 4 & 1,548 & 3 & 99.20 & 99.74 & 99.65 & 99.19 & 99.81 & 381.54 & $8.02 \times 10^{-3}$ \\
\hline $\begin{array}{l}\text { Positive } \\
\text { bacterial } \\
\text { culture and } \\
\mathrm{SCC} \geq 2 \times 10^{5} \\
\text { cells } / \mathrm{ml}\end{array}$ & 2,048 & 496 & 496 & - & 1,552 & - & 100 & 100 & 100 & - & - & - & - \\
\hline
\end{tabular}

Table 5. Evaluation of Fe, $\mathrm{Zn}, \mathrm{Co}, \mathrm{LDH}$ and ALP as an indicator for diagnosis of subclinical mastitis in riverine buffalo caused by gram positive bacteria only

\begin{tabular}{|c|c|c|c|c|c|c|c|c|c|c|c|c|c|}
\hline \multirow{2}{*}{$\begin{array}{l}\text { Name } \\
\text { of the } \\
\text { parameter }\end{array}$} & \multirow{2}{*}{$\begin{array}{c}\text { Total } \\
\text { samples } \\
\text { examined } \\
(\mathrm{N})\end{array}$} & \multirow{2}{*}{$\begin{array}{c}\text { Test } \\
\text { positive } \\
\text { samples } \\
(a+b)\end{array}$} & \multicolumn{4}{|c|}{$\begin{array}{l}\text { Test reaction as compared to cultural } \\
\text { examination }\end{array}$} & \multirow{2}{*}{$\begin{array}{c}\text { Percent } \\
\text { sensitivity } \\
\mathrm{a} /(\mathrm{a}+\mathrm{d}) \\
\times 100\end{array}$} & \multirow{2}{*}{$\begin{array}{l}\text { Percent } \\
\text { specificity } \\
\text { c/(b+c) } \\
\times 100\end{array}$} & \multirow{2}{*}{$\begin{array}{c}\text { Percent } \\
\text { accuracy } \\
(\mathrm{a}+\mathrm{c}) \\
/ \mathrm{N} \times 100\end{array}$} & \multirow{2}{*}{$\begin{array}{c}\text { Positive } \\
\text { predictive } \\
\text { value }(\%) \\
\mathrm{a} /(\mathrm{a}+\mathrm{b})\end{array}$} & \multirow{2}{*}{$\begin{array}{c}\text { Negative } \\
\text { predictive } \\
\text { value }(\%) \\
\mathrm{c} /(\mathrm{c}+\mathrm{d})\end{array}$} & \multirow{2}{*}{$\begin{array}{c}\text { Likelihood } \\
\text { ratio } \\
\text { (positive) } \\
\text { sensitivity } \\
/(100- \\
\text { specificity) }\end{array}$} & \multirow{2}{*}{$\begin{array}{l}\text { Likelihood } \\
\text { ration } \\
\text { (negative) } \\
\text { (100- } \\
\text { sensitivity) } \\
\text { /specificity }\end{array}$} \\
\hline & & & $\begin{array}{c}\text { True } \\
\text { positive } \\
\text { (a) }\end{array}$ & $\begin{array}{c}\text { False } \\
\text { positive } \\
\text { (b) }\end{array}$ & $\begin{array}{c}\text { True } \\
\text { negative } \\
\text { (c) }\end{array}$ & $\begin{array}{c}\text { False } \\
\text { negative } \\
\text { (d) }\end{array}$ & & & & & & & \\
\hline $\mathrm{Fe}$ & 1,964 & 369 & 305 & 64 & 1,488 & 107 & 74.03 & 95.88 & 92.29 & 82.66 & 93.29 & 17.96 & 0.27 \\
\hline $\mathrm{Zn}$ & 1,964 & 392 & 366 & 26 & 1,526 & 46 & 88.83 & 98.32 & 96.33 & 93.37 & 97.07 & 52.88 & 0.12 \\
\hline Co & 1,964 & 378 & 338 & 40 & 1,512 & 74 & 82.03 & 97.42 & 94.20 & 89.42 & 95.33 & 31.79 & 0.18 \\
\hline LDH & 1,964 & 385 & 352 & 33 & 1,519 & 60 & 85.44 & 97.87 & 95.26 & 91.43 & 96.20 & 40.11 & 0.15 \\
\hline ALP & 1,964 & 398 & 376 & 22 & 1,530 & 36 & 91.26 & 98.58 & 97.04 & 94.47 & 97.70 & 64.27 & 0.09 \\
\hline $\begin{array}{l}\text { Positive } \\
\text { bacterial } \\
\text { culture and } \\
\mathrm{SCC} \geq 2 \times 10^{5} \\
\text { cells } / \mathrm{ml}\end{array}$ & 1,964 & 412 & 412 & - & 1,552 & - & 100 & 100 & 100 & - & - & - & - \\
\hline
\end{tabular}


Table 6. Correlation coefficient of milk biochemical components in normal and SCM milk of riverine buffalo $(\mathrm{n}=496)$

\begin{tabular}{|c|c|c|c|c|c|c|c|c|c|c|c|c|}
\hline & \multicolumn{2}{|c|}{$\log _{10} \mathrm{SCC}$} & \multicolumn{2}{|c|}{$\mathrm{Fe}$} & \multicolumn{2}{|c|}{$\mathrm{Zn}$} & \multicolumn{2}{|c|}{ Co } & \multicolumn{2}{|c|}{$\mathrm{LDH}$} & \multicolumn{2}{|c|}{ ALP } \\
\hline & $\begin{array}{c}\text { Normal } \\
\text { milk }\end{array}$ & $\begin{array}{l}\text { SCM } \\
\text { milk }\end{array}$ & $\begin{array}{l}\text { Normal } \\
\text { milk }\end{array}$ & $\begin{array}{l}\text { SCM } \\
\text { milk }\end{array}$ & $\begin{array}{l}\text { Normal } \\
\text { milk }\end{array}$ & $\begin{array}{l}\text { SCM } \\
\text { milk }\end{array}$ & $\begin{array}{l}\text { Normal } \\
\text { milk }\end{array}$ & $\begin{array}{l}\text { SCM } \\
\text { milk }\end{array}$ & $\begin{array}{c}\text { Normal } \\
\text { milk }\end{array}$ & $\begin{array}{l}\text { SCM } \\
\text { milk }\end{array}$ & $\begin{array}{c}\text { Normal } \\
\text { milk }\end{array}$ & $\begin{array}{l}\text { SCM } \\
\text { milk }\end{array}$ \\
\hline $\log _{10} \mathrm{SCC}$ & - & - & -0.033 & 0.521* & -0.017 & 0.515* & -0.041 & 0.521* & 0.020 & $0.517 *$ & 0.033 & $0.805^{* *}$ \\
\hline $\mathrm{Fe}$ & - & - & - & - & 0.084 & 0.059 & -0.044 & 0.098 & 0.045 & 0.092 & 0.041 & 0.058 \\
\hline $\mathrm{Zn}$ & - & - & - & - & - & - & 0.017 & 0.055 & 0.067 & 0.025 & 0.088 & $0.529 *$ \\
\hline Co & - & - & - & - & - & - & - & - & -0.033 & 0.041 & -0.077 & 0.096 \\
\hline LDH & - & - & - & - & - & - & - & - & - & - & 0.065 & 0.109 \\
\hline
\end{tabular}

* Indicate significant at $\mathrm{p}<0.05$ and $* *$ indicate significant at $\mathrm{p}<0.01$.

N.B. $\mathrm{Cu}, \mathrm{Mn}$ and AST were not considered as they showed insignificant changes in normal and SCM milk.

considered together to diagnose SCM, the values were greater than $99 \%$ for all kinds of infections. The likelihood ration was also very high (Table 4).

\section{Udder profile correlation coefficient}

From Table 6 it can be observed that $\log _{10} \mathrm{SCC}$ is correlated $(\mathrm{p}<0.01)$ with ALP only in SCM milk. It is correlated with $\mathrm{Fe}$ and $\mathrm{Zn}$ in SCM at $\mathrm{p}<0.05$. Significant correlation $(\mathrm{p}<0.05)$ between ALP and $\mathrm{Zn}$ in SCM was also observed. No correlation between the components in normal milk was found. The correlation between $\mathrm{Zn}$ vs. ALP is shown in as scattered plot diagram (Figures 1 and 2).

\section{DISCUSSION}

The present study was carried out to evaluate trace minerals and enzymatic activities in milk as indicators of SCM, with special reference to bubaline subclinical mastitis.

The diagnosis of mastitis according to the International Dairy Federation (IDF) recommendations is based on the somatic cell counts (SCC) and microbiological status of the quarter (Guha et al., 2010). In the present study the milk samples satisfying two criteria viz. bacterial growth in culture media and $\mathrm{SCC} \geq 2 \times 10^{5}$, were considered positive for SCM (Gera and Guha, 2011b). Gram positive infections were most prevalent (Table 1) in the present investigation. Similar observations were reported by Chavan et al. (2007) and attributed to contamination of the organisms in the atmosphere of the tropics. The mean SCC in the SCM samples were significantly $(\mathrm{p}<0.01)$ high in SCM milk (Tables 2 and 3) owing to inflammatory reactions (Gera and Guha, 2011a).

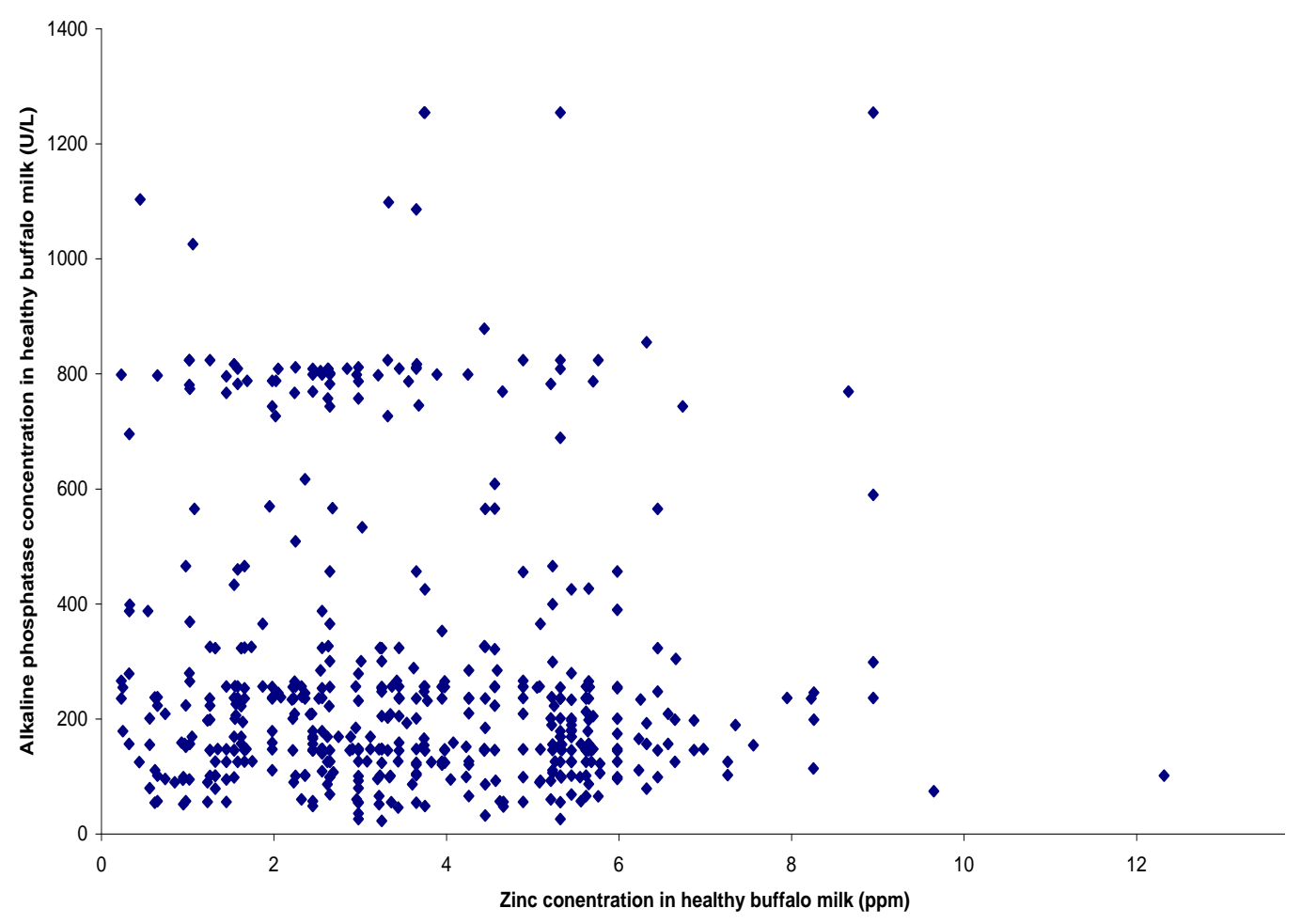

Figure 1. The scattered plot diagram of Zinc vs. Alkaline phosphatase concentration in healthy buffalo milk. 


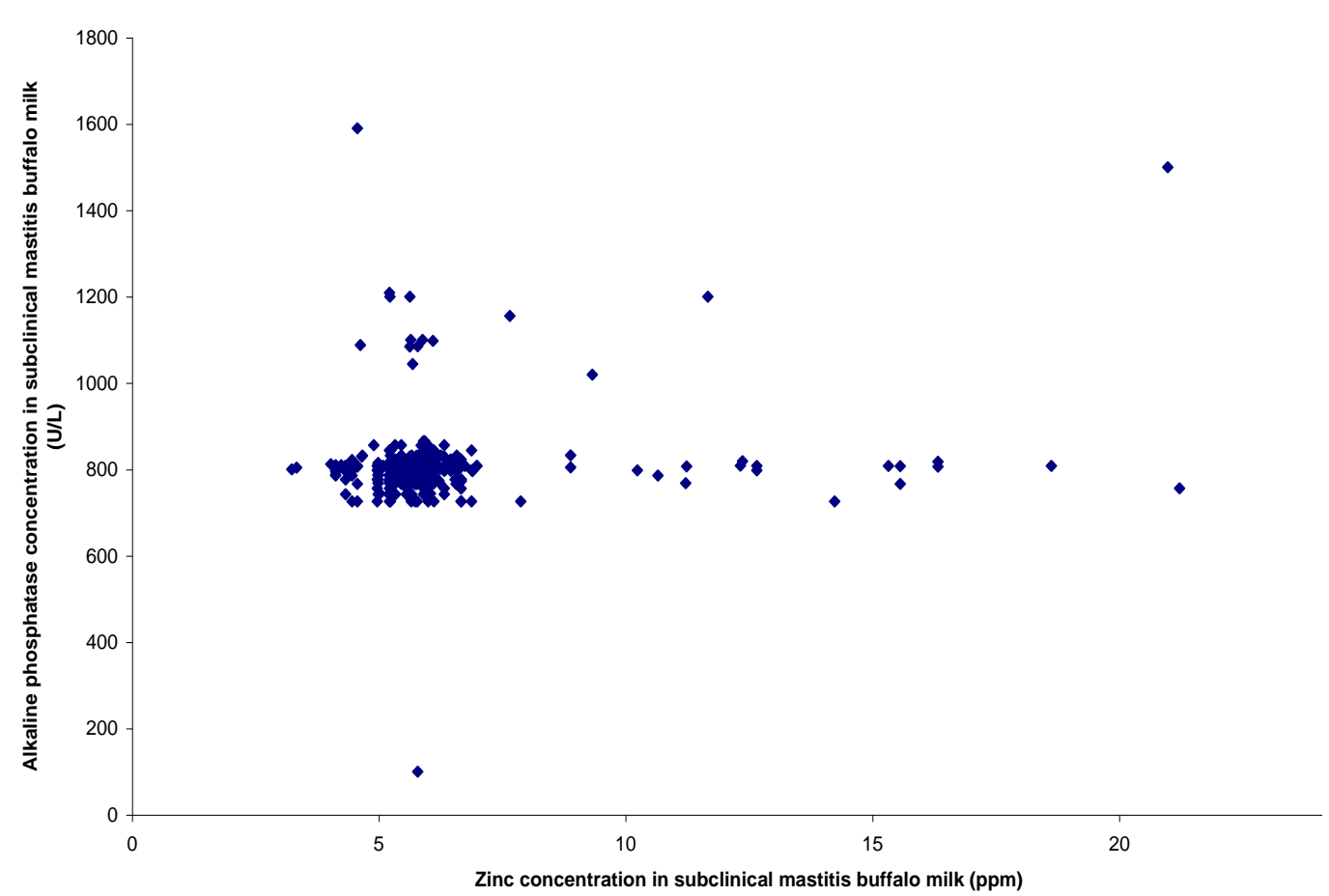

Figure 2. The scattered plot diagram of Zinc vs. Alkaline phosphatase concentration in subclinical mastitis buffalo milk.

It can be observed from Table 2 and 3 that the concentration of $\mathrm{Cu}, \mathrm{Mn}$ and AST were comparable in infected and normal milk, which agrees with the previous findings of Babaei et al. (2007) and Gera et al. (2011) in cow milk. Insignificant increase in $\mathrm{Cu}$ might be due to redistribution of the metal from liver to blood and finally to udder tissues and believed to be initiated by leukocytic endogenous mediators (Gera et al., 2011). Significant elevation of ALP (Tables 2 and 3) in SCM milk might be due to both mammary epithelial damage and a breach in the blood-milk barrier selectively damaged by bacterial toxins (Katsoulos et al., 2010). The origin of LDH in SCM milk is attributed to the presence of leucocytes and epithelial cells from the udder (Mohammadian, 2011). Katsoulos et al. (2010) reported that the origin of elevated LDH and ALP activity was from leukocyte and mammary epithelial and interstitial cells damaged during inflammation, particularly from disintegrated leukocytes.

The significant increase in the mean concentration of $\mathrm{Fe}$, $\mathrm{Zn}$ and $\mathrm{Co}$ in SCM milk was due to prevalence of Gram positive infections in the present study. The increase of these trace minerals is attributed to breach in mammary epithelial function (Gera et al., 2011) and increased permeability of the blood-milk barrier which permits trace minerals to shift into lacteal secretion (Zhao and Lacasse, 2008). The elevation of trace minerals in gram positive SCM samples might be due to the fact that gram positive bacteria are more pathogenic in the destruction of the mammary gland epithelia whereas $E$. coli are less damaging to mammary gland cells (Wenz et al., 2006).

Table 4 illustrates percent sensitivity, specificity and accuracy of each component in detecting SCM irrespective of etiological agent while Table 5 illustrates these factors for gram positive infections alone. It was evident that the values were highest for ALP followed by $\mathrm{Zn}$ for all types of bacterial infections. For SCM caused by Gram positive bacteria a high percent accuracy was also noticed for LDH followed by $\mathrm{Co}$ and $\mathrm{Fe}$ (Table 5). In fact, there was increase in sensitivity and positive predictive values for all the parameters including ALP and $\mathrm{Zn}$ in Gram positive bacterial infections. This might be due to the reduction in the false negative cases, attributed to omission of $E$. coli SCM where these components did not show an appreciable increase (Table 2). Similar findings for ALP and LDH were reported by Babaei et al. (2007), Katsoulos et al. (2010) and Gera and Guha (2011b) for mastitis in cow, ewe and doe milk. Percent sensitivity, specificity and accuracy for each component were determined separately for SCM milk containing gram positive bacterial infections alone, as earlier reports state that Gram positive bacteria are the most prevalent mastitogenic agent, especially Staphyloccocus spp. (Hadmili et al., 2005; Guha et al., 2010), the same was observed in the present investigation.

To assess the exactness of the tests, the predictive values and likelihood ratios were calculated. A positive predictive value indicates the proportions of animals with a positive test which are really diseased, whereas, the likelihood ratio of a positive test result expresses how much more likely the 
animal is to have a positive test result when actually diseased than if disease free (i.e. it is the ratio of the likelihoods of having and not having the disease). Likelihood test of a positive test result $>10$ indicates that the test can be used to rule in the disease. A likelihood ratio of a negative result describes how much more likely the animal is used to have a negative test result if it has the disease than if it is a disease free (Petrie and Watson, 2008). The likelihood ratio of positive test for all kinds of infections (Table 4) amongst all the parameters was higher for ALP followed by $\mathrm{Zn}$ (above 10 for both). The likelihood ratio of positive test for rest of the parameters was below 10 , indicating that they were not reliable to diagnose SCM. For Gram positive infections the value was greater than 10 for all the parameters (Table 5). For ALP and LDH the values were comparable with the observations of Gera and Guha (2011b) in cow milk, suggesting ALP as the indicator of SCM in crossbred cattle.

As we perceive from the present study the diagnosis of SCM, individually by ALP and $\mathrm{Zn}$ is not completely satisfactorily. Therefore, we tested them jointly. From Table 4 it is evident that when ALP and $\mathrm{Zn}$ are considered collectively to diagnose SCM, the result was very acceptable. The percent sensitivity, specificity, accuracy, positive predictive value was above 99 percent. The likelihood ratio was 381.54 , which means, a positive test result is 381.54 times more likely to occur in an animal that has the disease than in one which does not have it.

To the best of our knowledge no reports of ALP and LDH in buffalo milk and trace minerals in any type of animal milk regarding their value as diagnostic indicators of SCM exists to support our finding. Consequently, the present work is a pioneer study.

To be more precise, a double statistical evaluation for each presumed indicator was done in this study, Pearson's correlation coefficients were computed amongst the parameters correlating with $\log _{10} \mathrm{SCC}$ (Gold Standard test), separately in healthy and SCM milk (Table 6). It was observed that $\mathrm{Fe}, \mathrm{Zn}$, Co and $\mathrm{LDH}$ were highly correlated with $\log _{10} \mathrm{SCC}$ at $\mathrm{p}<0.05$ whereas, ALP was correlated with $\log _{10} \mathrm{SCC}$ at $\mathrm{p}<0.01$. This might be due to alternation in ALP concentration in SCM milk irrespective of the causative agents (Table 2). Significant correlation $(p<0.05)$ between ALP and Zn suggested they complement each other.

A scatter plot graph shows the relationship between two quantitative variables. Each case is a point, with the $\mathrm{x}$-coordinate representing one variable or parameter and the $\mathrm{y}$-coordinate representing another parameter. In the study at hand two scatter plot graphs for Zn vs. ALP were drawn, each, for healthy (Figure 1) and SCM (Figure 2) milk. Zn is represented by $\mathrm{x}$-coordinate and $\mathrm{y}$-coordinates representing ALP. For healthy milk we find that the points are dispersed whereas for SCM milk the points are clustered with a few points lying outside. The results of Pearson's correlation coefficients as found above also holds true for the scatter plots. In SCM milk a significant $(\mathrm{p}<0.05)$ positive correlation was observed. This might be due to the fact that both these parameters showed significant increases in concentration for SCM milk. However, no correlation was fond between them in healthy milk. Therefore, it is evident from the scatter plot that both $\mathrm{Zn}$ and ALP concentration in milk gets influenced by SCM in the same trend.

\section{IMPLICATIONS}

Dairy production is a significant part of anthropological culture and tradition that is frequently impaired by diseases of production viz., mastitis. Mastitis negatively affects the production longevity of dairy animals, the dairy production chain and quality of milk leading to poor milk processing capacities. Losses accumulate at the dairy producer level, due to culling of the infected animal, veterinary costs, extralabor costs, precluded milk, reduced slaughter value and abridged reproductive performance. In summary, it causes huge monetary losses world-wide (Sharma et al., 2010). The high social and economic prominence of mastitis has focused an intense research effort in the recent decades. Based upon the severity of the inflammatory response mastitis manifests itself in clinical and (or) subclinical form. Once mastitis reaches the clinical phase a confirmed economic loss has occurred as a proper effective cure is still a delusion for veterinarians. The negative effects of mastitis could last till the end of the productive life of the infected animal and often results in premature culling. Another problem associated with mastitis is the difficulty of preparing potent vaccines due to the diverse etiology of its causes (Gera and Guha, 2011). The only opportunity to avoid this catastrophe is diagnosis and treatment before the infection flares up, i.e. at the subclinical stage. But diagnosis of subclinical mastitis (SCM) is impracticable as changes in milk and udder is unapparent and cannot be monitored by the unaided eye. SCM as per previous reports is associated with elevated somatic cell count (SCC), where SCC level is often used as indication of the severity of the subclinical case. Despite the frequent use of SCC to represent subclinical cases, no consensus has yet been reached to define SCM based on SCC elevation (Guha et al., 2010). So an alternative path to decide upon is to develop putative indicators of SCM, which may be regarded the first step to fabricate a kit in the near future to detect SCM. There is a no. of indirect tests like the California Mastitis Test (CMT) etc. but their reliability is debatable among researchers. The present study is a part of the M.V.Sc. thesis of the first author and in this thesis research we used a no. 
of indirect tests including CMT, but the results were not satisfactory.

\section{CONCLUSION}

The present research article contains a valuable confirmation in reference to bubaline SCM. From nutritionist view point, increased bacteriological load not only makes SCM milk unfit for human consumption but also alters the trace minerals concentration and amends the food value of SCM milk. Moreover, SCM influences milk enzyme activity. From the current study it is evident that there is not a single indicator; instead we need an array of indicators to detect SCM. Although, ALP and Zn were found to be indicators of SCM (former being better and more reliable in the present study as ALP showed the highest agreement amongst all with IDF criteria of SCM diagnosis for all types of mastitis causing bacterial agents) it is recommended that they both to be considered together for screening large herds for SCM. In regions like the tropics, where Gram positive bacteria are prevalent, LDH, $\mathrm{Co}$ and $\mathrm{Fe}$ can also be incorporated in the screening programs if estimating ALP and $\mathrm{Zn}$ is not feasible. The threshold value for ALP and $\mathrm{Zn}$ is fixed at $811.12 \mathrm{U} / \mathrm{L}$ and $6.01 \mathrm{ppm}$, respectively. Standardizing easy biochemical methods or qualitative tests for estimating these indicators is recommended to develop kit for diagnosing SCM in the field. An attempt to develop a pathophysiological explanation of the ascertained association is also recommended for further study.

\section{REFERENCES}

Babaei, H., N. Mansouri, M. M. Molaei, A. Kheradmand and M. Sharifan. 2007. Assessment of lactate dehydrogenase, alkaline phosphatase and aspartate aminotransferase activities in cow's milk as an indicator of subclinical mastitis. Vet. Res. Commun. 31:419-425.

Chavan, V. V., S. U. Digraskar, S. N. Dhonde and P. B. Hase. 2007. Observation of bubaline subclinical mastitis in and around Parbhani. Ind. J. Field Vet. 3:50.

Gera, S. and A. Guha. 2011a. Assessment of acute phase proteins and nitric oxide as indicators of subclinical mastitis in Holstein $\times$ Haryana cattle. Ind. J. Anim. Sci. 81:1029-1031.
Gera, S. and A. Guha. 2011b. Evaluation of lactate dehydogenase, alkaline phosphatase and aspartate aminotransferase activity in milk as an indicator of subclinical mastitis in Holstein $\times$ Haryana cows. Ind. J. Vet. Res. 20 (In press).

Gera, S., A. Guha, A. Sharma and V. Manocha. 2011. Evaluation of trace element profile as an indicator of bovine sub-clinical mastitis. Int. Polivet. 12:9-11.

Gera, S., A. Sharma, R. S. Dabur, V. K. Jain and S. L. Garg. 2006. Studies on changes in milk composition and chemotherapeutic sensitivity in camel (Camelus dromedarius) in subclinical mastitis. In: Proceedings of the International Scientific Conference on Camels (Quassim University, Saudi Arabia), 2, 937-946.

Guha, A., S. Gera and A. Sharma. 2010. Assessment of chemical and electrolyte profile as an indicator of subclinical mastitis in riverine buffalo (Bubalus bubalis). Har. Vet. 49:19-21.

Hadmili, H. H., O. Erganiso, K. Kav and Z. Sayin. 2005. Evaluation of a combined vaccine against Staphylococcal mastitis in ewes. Bull. Vet. Inst. Pul. 49:179-182.

Hokmabad, R. V., M. F. Mogaddam, M. M. Sadegh and H. Mirzaii. 2011. Bacterial pathogens of intramammary infections in Azeri buffaloes of Iran and their antibiogram. Afr. J. Agric. Res. 6:2516-2521.

Katsoulos, P. D., G. Christodoulopoulos, A. Minas, M. A. Karatzia, K. Pourliotis and S. K. Kritas. 2010. The role of lactate dehydrogenase, alkaline phosphatase and aspartate aminotransferase in the diagnosis of subclinical intramammary infections in dairy sheep and goats. J. Dairy Res. 77:107-111.

Ma, J. L., J. F. Wang, L. X. Wu, T. Lai and Y. H. Zhu. 2006. Changes in micromineral, magnesium, cytokine and cortisol concentration in blood of dairy goats following intramammary inoculation with Staphylococcus aureus. J. Dairy Sci. 90:4679-4683.

Mohammadian, B. 2011. The effect of subclinical mastitis on lactate dehydrogenase in dairy cows. Int. J. Anim. Vet. Adv. 3:161-163.

Moroni, P., C. S. Rossi, G. Pisoni, V. Bronzo, B. Castiglioni and P. J. Boettcher. 2006. Relationships between somatic cell count and intra-mammary infection in buffaloes. J. Dairy Sci. 89:998-1003

Petrie, A. and P. Watson. 2008. Statistics for veterinary and animal science, Blackwell Publishing, London.

Sharma, N., V. Pandey and N. A. Sudhan. 2010. Comparisons of some indirect screening tests for detection of subclinical mastitis in dairy cows. Bul. J. Vet. Med. 13:98-103.

Wenz, J. R., G. M. Barrington, F. B. Garry, R. P. Ellis and R. J. Magnuson. 2006. Escherichia coli isolates' serotypes, genotypes and virulence genes and clinical coliform mastitis severity. J. Dairy Sci. 89:3408-3412.

Zhao, X. and P. Lacasse. 2008. Mammary tissue damage during bovine mastitis: Causes and control. J. Anim. Sci. 86:57-65. 